\title{
Personal columns
}

\section{The contribution of Henry Maudsley to the Institute of Psychiatry}

\author{
ISMOND Rosen, Psychotherapist/Analyst, 3 Hampstead Hill Gardens, London NW3 2PH
}

I am grateful of the honour the President and the College has bestowed on me in accepting the presentation by Lundbeck Pharmaceuticals of my bronzes of Henry Maudsley and Erwin Stengel, as part of the 150th Anniversary Celebrations. Special thanks are due to Professor Hugh Freeman for his assistance in this regard.

It is exactly 40 years to the week since I first arrived in Britain from South Africa, and I may now relate how Henry Maudsley played a significant role in the creation of the Institute of Psychiatry. I refer not to Maudsley the man, but to his bronze portrait. How did this come about, and what relevance can it have for the College today?

The answer follows the style of our Patron, the Prince of Wales in his Brighton address. He was able to amuse while reviewing the field of psychiatry historically, clinically, and scientifically, and at the same time elevating us into the realms of the spirit. However, I must do this much more briefly.

The Institute of Psychiatry, founded in 1947, was situated within The Maudsley Hospital until it moved to its new building in 1967. The man credited with its modern formation is, of course, Sir Aubrey Lewis.

How I ever was appointed a Maudsley registrar after Aubrey (as I shall refer to him) interviewed me 40 years ago remains a mystery to me still. In reply to his question, "What have you read?" all I could muster was 'Henderson \& Gillespie' and then proudly, "a book entitled Personality. "By whom?" asked Aubrey, but the author (Gardner Murphy) had gone completely out of my head. At which he relented, adding, "Don't worry. There are lots of books entitled Personality". Thus began my relationship with the redoubtable Professor. I informed him that I wished to take up my post in a year's time, in order to study art on the Continent, but he sagely limited me to six months.

Thus, in April 1952, having carved in stone at the Ecole des Beux Arts in Paris a copy of the head of St Paul from Chartres Cathedral, and absorbed Michelangelo's Moses in Rome, I commenced work at The Maudsley. Soon after, I proposed to Aubrey that the Institute mantelpiece would be enhanced

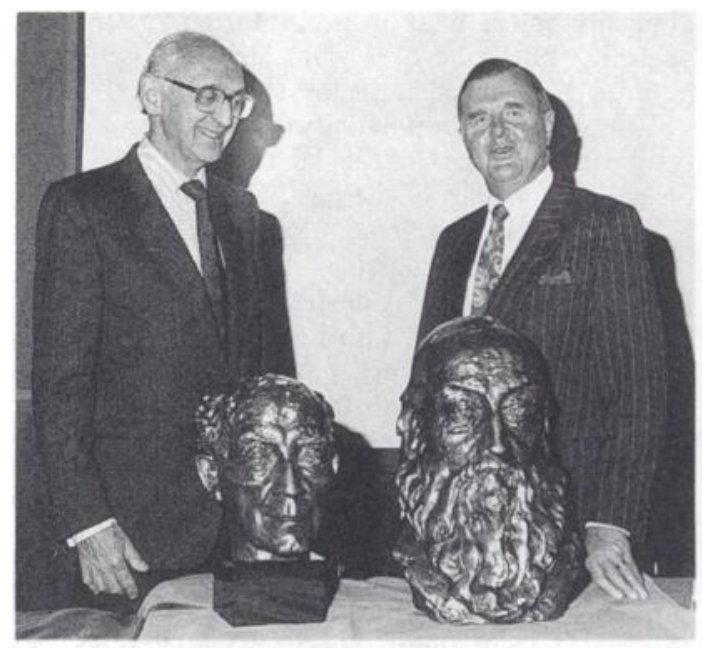

The sculptor, Dr Ismond Rosen (left) and Mr Colin Lynn, Chairman of Lundbeck Pharmaceuticals, with the busts of Erwin Stengel and Henry Maudsley, at the October 1991 Quarterly Meeting. The cost of casting the bronzes was paid by Lundbeck.

by a fine portrait of Henry Maudsley; he agreed to defray the $£ 50$ cost of bronzing.

I have of ten been asked how I manage to combine my psychiatric and artistic interests. In practice, the one has always helped the other. Having been successful with the recovery of a schizophrenic art student from the Royal College of Art, I was given the use of their sculpture studios where one late Saturday afternoon, while pouring and swirling the plaster of Paris into the negative mould of The Maudsley head, I managed to twist the filled negative mould off the chair on which I was working and it crashed to the ground in a soggy, fragmented mass. There was nothing else for me to do but bind up the pieces, pour in the rest of the fluid plaster, and hope for the best. When I told Aubrey about the catastrophe, he referred me to Benvenuto Cellini's Autobiography of Himself, which Goethe regarded as the best biography of a man of the 17th century, with 
its overcoming of sculptural disasters. In the event all turned out well, and the head of Maudsley found its way into the centre of the Royal Academy the following year, and then on to the mantelpiece outside Aubrey's office. But something had occurred during the dream which I never could account for, and only dimly comprehend even now.

Erwin Stengel was a brilliant clinician, an original thinker, and a great teacher. When I came to do a portrait of him a few years later, a mishap occurred with the finished clay portrait so that it had to be remodelled along the line of the mouth, losing the humour I had inserted. Aubrey, commenting sardonically on the final bronze, retorted "Here is his portrait, but where is Dr Stengel's sense of humour?". I cringed at the loss so apparent to all.

Thus, when the opportunity came to prepare these two bronzes for the College, I determined to improve on the misfortunes of the past. Stengel has had his hair completely abstracted to symbolically represent certain of his characteristics - his pearls of wisdom, his knowledge, and his devilish humour, the latter being represented by a horn on the right side. An example of his renowned humour was exemplified during a clinical demonstration in the old lecture theatre. The case he had chosen was particularly difficult, with highly abnormal features and impossible to diagnose clearly. Stengel presented the clinical phenomena meticulously and at the end of the hour, put his final questions to the patient. "I believe you come up to The Maudsley for some other purposes. Can you tell us about them?". "Yes, "replied the patient. "I come up to see Professor Eysenck". "What for"?, asked Stengel. "I am one of Professor Eysenck's normals", was the reply.

Thus The Maudsley head arrived on the mantelpiece outside his office. Only some years later did I hear that Aubrey, Lord of all he surveyed in British psychiatry, began to feel that Henry Maudsley was watching him from the mantelpiece. Not in the mundane sense of a delusional idea, but nobly, that perhaps he should be doing better - the ego ideal, raised to the highest level. He tried to avoid the stern gaze by using the passage entrance to his office, but by now it was internalised and the manoeuvre was to no avail. There was only one thing for it. He had to escape. Build a new Institute, bigger and better, with a grand building, where the bust of Henry Maudsley would be perched out of harm's way on the main staircase, exerting its mana only on the registrars. This state of affairs still prevails today, as I have ascertained from Professor Gerald Russell.

In Fraser's Golden Bough, R. H. Codrington, working with the Melanesians, defined mana as that invisible power by which men control the forces of nature, cause sickness, or remove it. Wizards, doctors and prophets work by this power or mana, which they impart to other men or objects. Generally, one man knows how to do one thing with it, and another one another.

Was the mana exerted upon Aubrey Lewis to develop the Institute imparted to the sculpture as a function of the dream during which the negative mould was necessitously and ceremoniously smashed at the Royal College of Art?

These are serious questions for the College, for it takes possession today of two portraits full of mana. Both were seriously damaged in their remodelled state during someone's dream at the bronze foundry: Maudsley was totally destroyed and what the College takes possession of is Maudsley mark 3.

What does the College wish to achieve with these enhanced ancestral figures? We don't need a new Institute or College building. What we do need is to redirect those energies brought to this country by psychiatric students worldwide, together with our native scientific wisdom. Let us carry British scientific psychiatry into the next century, into the Common Market, to the awakened Eastern European states where we have materially helped to end the abuses of psychiatry, and to the developing countries.

We are going to have some powerful forces standing on one of the College mantelpieces and next to the internalised stairs. 